\title{
Alteration of Pulmonary Artery Integrin Levels in Chronic Hypoxia and Monocrotaline-Induced Pulmonary Hypertension
}

\author{
Anita Umesh ${ }^{\mathrm{a}}$ Omkar Paudel $^{\mathrm{a}}$ Yuan-Ning Cao ${ }^{\mathrm{a}}$ Allen C. Myers ${ }^{\mathrm{b}}$ \\ James S.K. Sham ${ }^{\text {a }}$ \\ Divisions of a Pulmonary and Critical Care Medicine and ${ }^{b}$ Clinical Immunology, Department of Medicine, \\ Johns Hopkins School of Medicine, Baltimore, Md., USA
}

\section{Key Words}

Integrins $\cdot$ Chronic hypoxia $\cdot$ Monocrotaline $\cdot$ Pulmonary

hypertension $\cdot$ Pulmonary arteries

\begin{abstract}
Background: Pulmonary hypertension is associated with vascular remodeling and increased extracellular matrix (ECM) deposition. While the contribution of ECM in vascular remodeling is well documented, the roles played by their receptors, integrins, in pulmonary hypertension have received little attention. Here we characterized the changes of integrin expression in endothelium-denuded pulmonary arteries (PAs) and aorta of chronic hypoxia as well as monocrotaline-treated rats. Methods and Results: Immunoblot showed increased $\alpha_{1^{-}}, \alpha_{8^{-}}$and $\alpha_{v}$-integrins, and decreased $\alpha_{5}$-integrin levels in PAs of both models. $\beta_{1}$ - and $\beta_{3}$-integrins were reduced in PAs of chronic hypoxia and monocrotaline-treated rats, respectively. Integrin expression in aorta was minimally affected. Differential expression of $\alpha_{1}$ - and $\alpha_{5}$-integrins induced by chronic hypoxia was further examined. Immunostaining showed that they were expressed on the surface of PA smooth muscle cells (PASMCs), and their distribution was unaltered by chronic hypoxia. Phosphorylation of focal adhesion kinase was augmented in PAs of chronic
\end{abstract}

hypoxia rats, and in chronic hypoxia PASMCs cultured on the $\alpha_{1}$-ligand collagen IV. Moreover, $\alpha_{1}$-integrin binding hexapeptide GRGDTP elicited an enhanced $\mathrm{Ca}^{2+}$ response, whereas the response to $\alpha_{5}$-integrin binding peptide GRGDNP was reduced in CH-PASMCs. Conclusion: Integrins in PASMCs are differentially regulated in pulmonary hypertension, and the dynamic integrin-ECM interactions may contribute to the vascular remodeling accompanying disease progression.

Copyright $\odot 2011$ S. Karger AG, Basel

\section{Introduction}

Pulmonary hypertension is characterized by a sustained rise in the pulmonary arterial pressure that results from pulmonary vasoconstriction and vascular remodeling [1]. Pulmonary vascular remodeling involves increased pulmonary arterial cell proliferation and hypertrophy, leading to thickening of the pulmonary arterial wall. Another underlying feature of pulmonary vascular remodeling that accompanies pulmonary hypertension is an increase in the deposition of extracellular matrix (ECM) components, particularly collagen, elastin, tenascin- $\mathrm{C}$ and fibronectin, which have been documented in both human and animal models of the disease [1-4]. The

\section{KARGER}

() 2011 S. Karger AG, Basel

Fax +41613061234 E-Mail karger@karger.ch www.karger.com www.karger.com/jvr
Dr. James S.K. Sham

Division of Pulmonary and Critical Care Medicine

Johns Hopkins Asthma and Allergy Center, 5501 Hopkins Bayview Circle Baltimore, MD 21224 (USA)

Tel. +1 410550 7751, E-Mail jsks@ jhmi.edu 
increased deposition of matrix proteins in the pulmonary vasculature has been attributed to increases in serine elastase activity, as well as a change in the balance of matrix metalloproteinase (MMP) and tissue inhibitors of metalloproteinase (TIMP) activity $[5,6]$. The importance of elastase/proteinase in pulmonary vascular remodeling is exemplified in animal models of pulmonary hypertension. For example, inhibition of serine elastase activity reversed pulmonary hypertension both in rats exposed to chronic hypoxia as well as monocrotaline (MCT) $[5,7]$, while inhibition of MMPs by gene transfer of a human TIMP1 gene attenuated and aggravated vascular remodeling, respectively, in rats treated with MCT and chronic hypoxia [6]. Additionally, the specific MMP inhibitor Batimastat, which has no influence on systemic circulation, attenuated pulmonary hypertension in chronically hypoxic rats [6].

While the importance of matrix components in pulmonary vascular remodeling has been implicated extensively in the development of pulmonary hypertension, relatively little attention has been paid to the involvement of integrins, the receptors for the ECM proteins. Integrins comprise a superfamily of structurally related heterodimeric transmembrane receptors that mediate cell-cell and cell-matrix interactions. They physically bridge the ECM and the cytoskeleton, acting as transducers of 'outside-in' and 'inside-out' signaling [8]. Of the $18 \alpha$ - and 8 $\beta$-subtypes that have been identified to date, $\alpha_{1-9}, \alpha_{\mathrm{v}}, \beta_{1}$, $\beta_{3}, \beta_{4}$ and $\beta_{5}$ integrins have been reported in vascular smooth muscle cells (SMCs), and $\alpha_{1-5}, \alpha_{7}, \alpha_{8}, \alpha_{v}, \beta_{1}, \beta_{3}$ and $\beta_{4}$ integrins have been detected in the pulmonary vasculature [8-10]. Integrins play important roles in various vascular functions, including mechano-transduction, myogenic response, ECM synthesis, SMC proliferation, apoptosis and migration, neointimal formation, and eutrophic inward remodeling $[9,11]$. In the pulmonary vasculature, we showed that integrin-binding hexapeptides are capable of mobilizing intracellular $\mathrm{Ca}^{2+}$ in pulmonary arterial smooth muscle cells (PASMCs). We further showed that one of these peptides, namely GRGDSP, mobilizes intracellular $\mathrm{Ca}^{2+}$ from ryanodine receptorgated organelles and lysosome-related acidic organelles, by causing an increase in cyclic ADP ribose [10]. In the context of pulmonary hypertension, the involvement of $\alpha_{v} \beta_{3}$ integrin has thus far been documented in MCTtreated rats, where the elastase-mediated activation of MMPs leads to $\alpha_{v} \beta_{3}$ integrin clustering and subsequent transcription of tenascin-C and an increase in SMC proliferative response to growth factors $[1,12,13]$.
In this study we hypothesized that integrins are regulated concurrently with the increased deposition of ECM components observed in the development of pulmonary hypertension. To test this hypothesis, we took advantage of two different rat models of pulmonary hypertension, namely the chronic hypoxia and MCT-induced models, in order to discriminate between the direct effects of experimental treatments (that is, hypoxia or MCT) versus those related to the resultant vascular remodeling. In doing so, we systematically compared the differences in the expression of a number of $\alpha$ and $\beta$ integrin proteins specifically in endothelium-denuded pulmonary arteries (PAs) and aorta, in contrast to previous gene expression profiling studies that have taken a global approach using mostly extracts from whole lung tissues [for review, see 14]. We further confirmed the expression of the integrins in small PAs by immunohistochemistry, compared focal adhesion kinase (FAK) phosphorylation in PAs and PASMCs, and correlated the changes in function by monitoring the $\left[\mathrm{Ca}^{2+}\right]_{i}$ responses generated by integrin-specific peptide ligands in PASMCs of the chronic hypoxia rat model.

\section{Materials and Methods}

\section{Chronic Hypoxia and MCT Treatment}

Male Wistar rats (150-200 g) were used for all treatments. Hypoxic pulmonary hypertension was induced by exposure to normobaric hypoxia $\left(10 \% \mathrm{O}_{2}\right)$ for 4 weeks, while normoxic controls were reared in room air for the same period of time. MCT-induced pulmonary hypertension was developed by injection with a single subcutaneous dose of MCT ( $60 \mathrm{mg} / \mathrm{kg}$; Sigma). Animals were sacrificed 24 days later. All animals were anesthetized with sodium pentobarbital ( $130 \mathrm{mg} / \mathrm{kg}$ intraperitoneally) prior to removing the heart and lungs. Development of pulmonary hypertension was validated in both models by confirming right ventricular hypertrophy, which was done by separating the right ventricle (RV) from the left ventricle plus septum $(\mathrm{LV}+\mathrm{S})$, weighing these components and calculating the ratio of $\mathrm{RV} /(\mathrm{LV}+\mathrm{S})$. All animal procedures were performed in accordance with the guidelines specified by the Johns Hopkins Animal Care and Use Committee.

\section{Isolation of PAs and PASMCs}

PAs were dissected and PASMCs were enzymatically isolated as previously described [15]. Briefly, lungs were removed from male Wistar rats (150-200 g) anesthetized with sodium pentobarbital (130 mg/kg intraperitoneally), upon which intrapulmonary arteries of 3rd and higher generations (inner diameter approx. 0.3-1 mm) were dissected in HEPES-buffered salt solution (HBSS) containing (in mM) $130 \mathrm{NaCl}, 5 \mathrm{KCl}, 1.2 \mathrm{MgCl}_{2}, 1.5 \mathrm{CaCl}_{2}, 10$ HEPES and 10 glucose, $\mathrm{pH}$ 7.4. PAs were cut open, carefully cleaned of connective tissue, and the endothelial layer was removed by rubbing the luminal surface thoroughly with a cotton swab. Arteries were stored at $-80^{\circ} \mathrm{C}$ for Western blot analysis. For 
enzymatic isolation of PASMCs, arteries were incubated in icecold HBSS (30 min), and then in reduced-Ca ${ }^{2+}(20 \mu \mathrm{M})$ HBSS $(20$ min, room temperature), upon which they were digested in reduced $\mathrm{Ca}^{2+} \mathrm{HBSS}$ containing collagenase (type I, 1,750 U/ml), papain $(9.5 \mathrm{U} / \mathrm{ml})$, bovine serum albumin $(2 \mathrm{mg} / \mathrm{ml})$ and dithiothreitol $(1 \mathrm{mM})$ at $37^{\circ} \mathrm{C}$ for $18 \mathrm{~min}$. After washing with $\mathrm{Ca}^{2+}$-free HBSS, single SMCs were gently dispersed from the tissues by trituration in $\mathrm{Ca}^{2+}$-free HBSS. PASMCs were plated on $25-\mathrm{mm}$ glass cover slips for $\mathrm{Ca}^{2+}$ fluorescence experiments or on $35-\mathrm{mm}$ culture dishes, which were noncoated or coated with human collagen type IV or fibronectin (BD Biosciences), for determination of FAK phosphorylation. PASMCs isolated from normoxic and chronic hypoxic rats and normoxic rats were transiently cultured under normoxic condition (air $+5 \% \mathrm{CO}_{2}$ ) or in a modular incubator chamber (Billups-Rothenberg) containing 4\% $\mathrm{O}_{2}$ and $5 \% \mathrm{CO}_{2}$ $\left(16-24 \mathrm{~h}, 37^{\circ} \mathrm{C}\right)$.

\section{Preparation of Protein Samples and Immunoblot}

Total protein was isolated from PAs, aorta, and cultured PASMCs for Western blot analysis of integrin expression and phosphorylation of FAK. Endothelium-denuded PAs and aorta were frozen in liquid nitrogen, pulverized and homogenized with a Dounce homogenizer (30 strokes) in ice-cold Tris- $\mathrm{HCl}$ buffer (50 mM, pH 7.4) containing phenylmethylsulfonyl fluoride (1 mM) and protease cocktail inhibitor (Roche). Homogenized tissues or cultured cell lysate were centrifuged $\left(3,000 \mathrm{~g}, 4^{\circ} \mathrm{C}, 10 \mathrm{~min}\right)$, upon which the protein concentrations of the postnuclear supernatant were measured with the BCA Protein Assay Kit (Pierce). Protein samples were analyzed by SDS-PAGE and immunoblot. They were treated with Laemmli sample buffer with (for integrin $\beta_{3}$ ) or without (for all other integrin subtypes) $\beta$-mercaptoethanol $\left(100^{\circ} \mathrm{C}, 5 \mathrm{~min}\right)$, separated by an $8 \%$ polyacrylamide gel $(5 \mu \mathrm{g}$ per lane), and electrotransferred onto Immobilon P membranes (0.45 $\mathrm{mm}$; Millipore) using a tank transfer system $\left(80 \mathrm{~V}, 3 \mathrm{~h}, 4^{\circ} \mathrm{C}\right)$. Upon blocking ( $1 \mathrm{~h}$, room temperature) with $5 \%$ skim milk in PBS containing $0.05 \%$ Tween-20 (PBST), membranes were incubated with primary antibodies diluted in PBST containing 3\% BSA (BSA/ PBST) at $4^{\circ} \mathrm{C}$ overnight. The following primary antibodies were used: integrin $\alpha_{1}$ (1:1,000, AB1934; Chemicon International); $\alpha_{5}$ (1:1,000, AB1949; Chemicon); $\alpha_{8}$ (1:2,500; generous gift from Dr. Lynn Schnapp, University of Washington); $\alpha_{\mathrm{v}}(1: 250,611012 ; \mathrm{BD}$ Biosciences); $\beta_{1}$ (1:2,000, AB1952; Chemicon); $\beta_{3}$ (1:500, 4702; Cell Signaling); total FAK (1:1,000, 06-543; Millipore); phosphoFAK (1:1,000, 44-624G; Invitrogen); Actin (1:5,000, SC-1615; Santa Cruz). After washing in PBST, membranes were incubated with horseradish peroxidase-coupled donkey-anti-rabbit or sheepanti-mouse secondary antibodies (Amersham Biosciences) diluted in $1 \%$ BSA/PBST ( $1 \mathrm{~h}$, room temperature), and again washed extensively. Protein signal was then detected using enhanced chemiluminescence (Pierce Biotechnologies), and intensity was quantified using a Gel Logic 200 Image System (Kodak).

\section{Immunostaining of Lung Section and PASMCs}

Lung tissues were fixed in $4 \%$ formaldehyde in PBS $(0.05 \mathrm{M}$ phosphate buffer, $0.9 \%$ sodium chloride, $\mathrm{pH} 7.4$ ), rinsed in $\mathrm{PBS}$ and cryoprotected with $18 \%$ sucrose in PBS $\left(24 \mathrm{~h}, 4^{\circ} \mathrm{C}\right)$. Alternate cryostat sections $(10 \mu \mathrm{m})$ were collected on lysine-coated slides, dried briefly, and blocked with $1 \%$ BSA and $10 \%$ normal goat serum $(60$ min, room temperature). For immunostaining $\alpha_{8}$ integrin, a tyramine signal amplification kit (Perkin Elmer) was used; for these sections, prior to blocking with goat serum, endogenous peroxidase activity was blocked with hydrogen peroxide (3 in 50\% methanol in PBS, $30 \mathrm{~min}$ ). The sections were then incubated overnight $\left(4^{\circ} \mathrm{C}\right)$ in a rabbit antibody recognizing individual integrins (same antibodies as used for immunoblotting) and mouse monoclonal antibody recognizing smooth muscle $\alpha$-actin (Abcam Inc.) diluted in PBS containing 1\% BSA, 0.5\% Triton X-100). Separate sections were processed similarly for negative control except the primary antibody was replaced with rabbit IgG to evaluate nonspecific staining. For tyramine signal amplification, sections were incubated with peroxidase-conjugated goat anti-rabbit immunoglobulin $(1 \mu \mathrm{g} / \mathrm{ml})$ and then with Alexa Fluor 488 -conjugated tyramide (Molecular Probes) in amplification solution; otherwise, sections were incubated with goat anti-rabbit conjugated with Alexa Fluor 488 and goat anti-mouse conjugated with Alexa Fluor 594. Washed slides were mounted in Tris-buffered glycerol ( $\mathrm{pH} 8.6)$.

PASMCs from normoxic and hypoxic rats were placed on polyL-lysine $\left(0.01 \% \mathrm{w} / \mathrm{v}\right.$ in $\mathrm{H}_{2} \mathrm{O}$; Sigma) coated $25 \mathrm{~mm}$ cover glass and incubated at $37^{\circ} \mathrm{C}$ in Ham's F-12 medium under air and $5 \% \mathrm{CO}_{2}$ or $4 \% \mathrm{O}_{2}$ and $5 \% \mathrm{CO}_{2}$ in a modular incubator chamber (BillupsRothenberg), respectively, for $5 \mathrm{~h}$. Cells were fixed with $4 \%$ formaldehyde in PBS (pH 7.4) for 10 min and incubated overnight at $4{ }^{\circ} \mathrm{C}$ with primary antibodies for integrin $\alpha_{1}$ (1:400 dilution; Chemicon AB1934) and $\alpha_{5}$ (1:100 dilution; Chemicon AB1949) in the presence of $1 \%$ normal goat serum. $\mathrm{Cy}^{\mathrm{TM}} 3$-conjugated goat anti-rabbit IgG (1:800 dilution, 111-165-144; Jackson Immuno) was used for secondary antibody incubation for $1 \mathrm{~h}$ at room temperature. After mounting the cover glass, images were captured using a Carl Zeiss LSM510 confocal microscope.

\section{Calcium Imaging}

PASMCs were loaded with fluo-3 AM dissolved in DMSO containing $20 \%$ pluronic acid $(10 \mu \mathrm{M})$ for $45 \mathrm{~min}$ at room temperature (Molecular Probes). Upon washing thoroughly with Tyrode solution containing (in $\mathrm{mM}$ ) $137 \mathrm{NaCl}, 5 \mathrm{KCl}, 2 \mathrm{CaCl}_{2}, 1 \mathrm{MgCl}_{2}, 10$ D-glucose and 10 NaHEPES (pH 7.4 adjusted with $\mathrm{NaOH}$ ), the cytosolic dye was allowed to de-esterify for $20 \mathrm{~min}$. Fluo-3 fluorescence of PASMCs were detected under a Nikon Diaphot microscope equipped with epifluorescence attachments and a microfluorometer (model D-104; PTI). After a stable resting $\left[\mathrm{Ca}^{2+}\right]_{\mathrm{i}}$ was attained for more than $10 \mathrm{~min}$, the integrin-specific ligands GRGDTP and GRGDNP were applied to PASMCs and the fluorescent signal was recorded for $15 \mathrm{~min}$. The $\mathrm{Ca}^{2+}$ response of both normoxic and hypoxic PASMCs was examined under normoxic conditions for the comparison of integrin-dependent response in the absence of acute influence of hypoxia intracellular $\left[\mathrm{Ca}^{2+}\right]_{\mathrm{i}}$. Protocols were executed and data collected on-line with a Digidata analog-to-digital interface and the pClamp software package (Axon Instruments Inc.). Fluorescence intensity $(\mathrm{F})$ was used to calculate the intracellular concentrations of $\mathrm{Ca}^{2+}:\left[\mathrm{Ca}^{2+}\right]_{\mathrm{i}}=\left[\mathrm{K}_{\mathrm{D}}\right.$. $\left.\left(\mathrm{F}-\mathrm{F}_{\mathrm{bg}}\right)\right] /\left(\mathrm{F}_{\max }-\mathrm{F}\right)$, where $\mathrm{F}_{\mathrm{bg}}$ is the background fluorescence and $\mathrm{F}_{\max }$ is the maximum fluorescence. Values for $\mathrm{F}_{\max }$ were determined in situ by superfusing the cells with the $10 \mu \mathrm{M} \mathrm{Ca}^{2+}$ ionophone 4-Br-A23187 (EMD Biosciences), and values for $\mathrm{F}_{\mathrm{bg}}$ were obtained in an area devoid of cells upon $\mathrm{Mn}^{2+}$ quenching.

\section{Statistical Analysis}

Data are expressed as means \pm SEM. The numbers of cells are specified in the text. Statistical significance $(p<0.05)$ was assessed by paired or unpaired Student's t tests or ANOVA with 
Newman-Keuls post hoc analyses wherever applicable. For Western blot analysis of integrin subtypes, each sample represented protein isolated from one animal and was normalized to the average intensities of control samples within each blot. Control-normalized values were then averaged between replicate blots. FAK phosphorylation was quantified by the ratio of the phospho-FAK signal over total FAK signal for each sample. Conventional housekeeping genes, such as smooth muscle $\alpha$-actin, $\beta$-actin, GAPDH and cyclophilin are regulated with hypoxia $[16,17]$. Immunoblot analysis of smooth muscle $\alpha$-actin, and $\beta$-actin were consistently regulated in these experiments, and were therefore not used as loading controls. Instead, protein concentration was used to ensure even loading, and a large sample size was used to minimize random errors resulting from pipetting.

\section{Results}

\section{Validation of the Rat Models of Pulmonary}

Hypertension

Right ventricular hypertrophy as measured by comparing the mass ratio, $\mathrm{RV} /(\mathrm{LV}+\mathrm{S})$, was used to confirm the development of pulmonary hypertension in chronic hypoxia and MCT-treated animals. RV/ $(\mathrm{LV}+\mathrm{S})$ was significantly elevated in rats exposed to 4 weeks of chronic hypoxia (normoxia: $0.276 \pm 0.004, \mathrm{n}=48$; hypoxia: 0.52 $\pm 0.01, \mathrm{n}=46, \mathrm{p}<0.001)$ and in rats 3 weeks after MCT injection (control: $0.265 \pm 0.005, \mathrm{n}=27$; MCT: $0.53 \pm$ $0.03, \mathrm{n}=25, \mathrm{p}<0.001)$

\section{Effect of Chronic Hypoxia on Integrin Protein Levels}

We investigated the effect of chronic hypoxia on selected integrin subtypes at the protein level by immunoblot analysis. Chronic hypoxia significantly elevated $\alpha_{8}$ integrin protein levels by $51.7 \pm 14.9 \%$ compared to normoxic controls ( $\mathrm{p}<0.007, \mathrm{n}=12$ animals), along with the levels of integrins $\alpha_{1}$ and $\alpha_{\mathrm{v}}(45.6 \pm 6.4 \%, \mathrm{p}<0.001, \mathrm{n}=$ 12 animals for $\alpha_{1} ; 45.1 \pm 10.0 \%, \mathrm{p}<0.002, \mathrm{n}=15$ animals for $\alpha_{\mathrm{v}}$ ) (fig. 1a, b). On the other hand, integrin $\alpha_{5}$ and $\beta_{1}$ protein levels were decreased in PAs isolated from chronically hypoxic rats $\left(-36.6 \pm 6.1 \%, \mathrm{p}<0.001\right.$, for $\alpha_{5} ;-35.5$ $\pm 6.7 \%, \mathrm{p}<0.001$, for $\beta_{1} ; \mathrm{n}=15$ animals each) (fig. 1a, b). In contrast to the significant changes in protein expression observed in the PA, chronic hypoxia affected integrin levels minimally in the aorta (fig. 1c, d), in which only the expression of $\alpha_{8}$ integrin was reduced to statistically significant levels by chronic hypoxia (-16.6 $\pm 3.5 \%$, $\mathrm{p}<0.001, \mathrm{n}=16$ animals).

\section{Effect of MCT Treatment on Integrin Protein Levels}

To distinguish whether the changes in integrin expression were due to direct effects of hypoxia or to pul- monary vascular remodeling, we turned to the MCT model of pulmonary hypertension. As shown in figure $2 \mathrm{a}$ and $b$, the changes in integrin protein expression were more pronounced in the PAs of MCT-treated animals. $\alpha_{1}$ integrin expression was most dramatically increased, by $149 \pm 36 \%(\mathrm{p}=0.004, \mathrm{n}=11$ animals $)$, when compared to controls. This was followed by $\alpha_{8}$ and $\alpha_{\mathrm{v}}$ integrins, which were increased by $71.4 \pm 14.8 \%(\mathrm{p}<0.001, \mathrm{n}=11$ animals) and $65.1 \pm 19.5 \%(\mathrm{p}=0.006, \mathrm{n}=11$ animals $)$, respectively. Levels of $\alpha_{5}$ and $\beta_{3}$ integrins were reduced in PAs isolated from MCT-treated animals by $24.7 \pm$ $6.7 \%(\mathrm{p}=0.006, \mathrm{n}=11$ animals $)$ and $26.2 \pm 10.8 \%(\mathrm{p}=$ $0.034, \mathrm{n}=11$ animals) respectively. Protein levels of integrin $\beta_{1}$, while unaffected in PAs, were increased by 37.8 $\pm 13.6 \%(\mathrm{p}=0.015, \mathrm{n}=11$ animals $)$ in aorta isolated from MCT-treated animals (fig. 2c, d).

\section{Detection of Integrin Expression by}

Immunohistochemistry

We further examined the expression of integrins in small PA in lung sections using double immunofluorescent staining. Positive signals were detected in small PAs using specific antibodies against $\alpha_{1}, \alpha_{5}, \alpha_{8}, \beta_{1}$, and $\beta_{3}$ integrins, which overlapped with the signals of smooth muscle-specific $\alpha$-actin (fig. 3), indicating that they originated from SMCs of small PAs. These results are consistent with the immunoblot studies using large PAs demonstrating integrin expression in PA smooth muscle. Immunoreactivities of various integrin subtypes were also detected in cells other than smooth muscle, but their signal levels were generally higher in actin-positive cells. However, immunohistochemistry was unsuitable for quantitative comparison of integrin expression in PAs of the chronic hypoxia and MCT models due to possible variability introduced by sectional plains, size of smooth muscle layer and sample processing. Differential expression of $\alpha_{1}$ and $\alpha_{5}$ integrins was further investigated in PASMCs of chronic hypoxia rat. Confocal imaging detected clear immunoreactivity of $\alpha_{1}$ and $\alpha_{5}$ integrins in the peripherial regions of PASMCs isolated from normoxic and chronic hypoxic rats (fig. 4a, b), suggesting that the integrin proteins were expressed predominantly on the cell surface. Cell surface expression of integrin was similar in normoxic and chronic hypoxic cells. The signals for $\alpha_{1}$ integrin were generally stronger, while those for $\alpha_{5}$ integrin were weaker, in the hypoxic PASMCs when they were recorded using the same settings for confocal imaging. However, variability of immunofluorescence signals in different samples precluded quantitative comparison. 


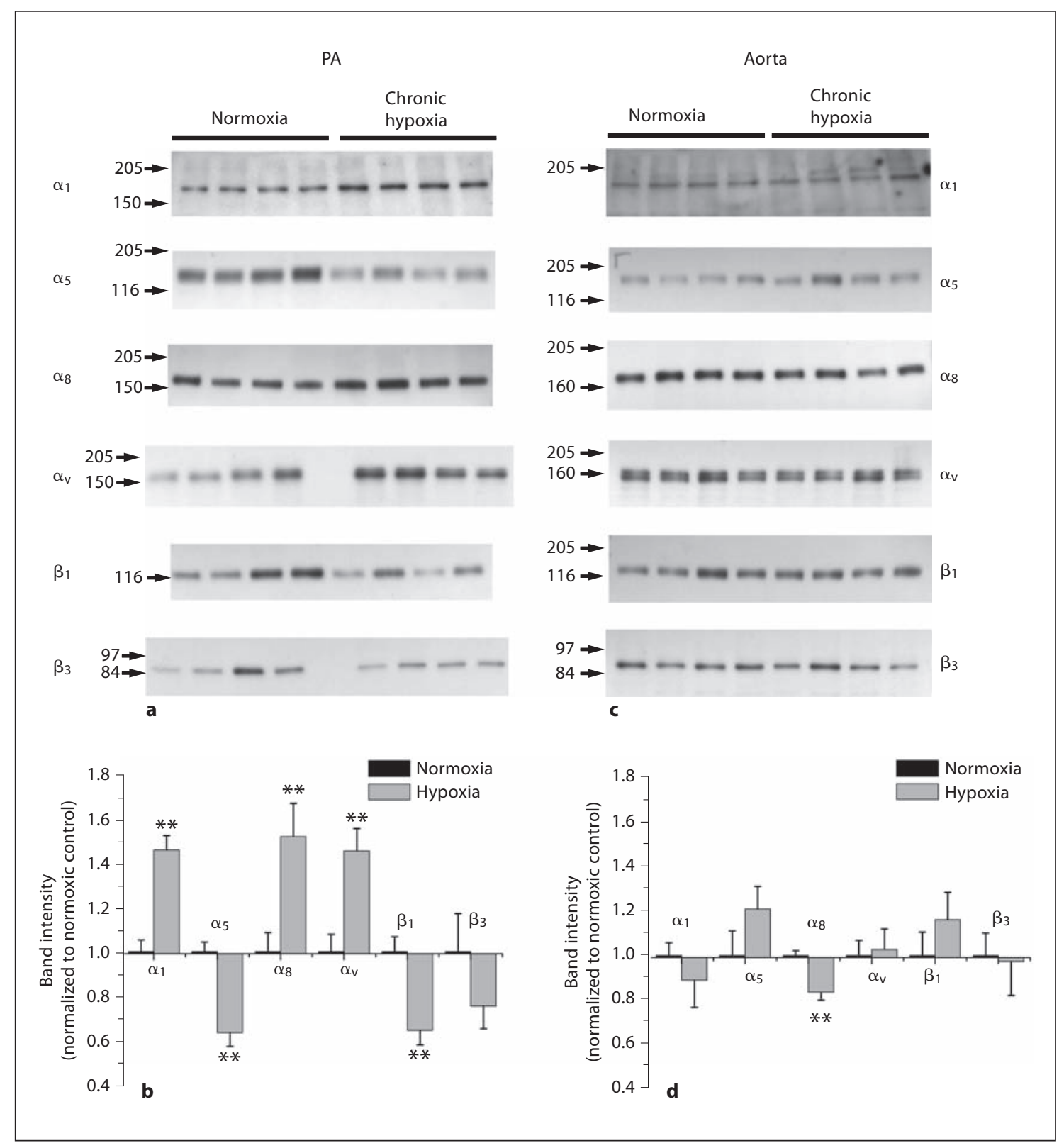

Fig. 1. Representative immunoblots of integrin proteins in endothelium-denuded PA (a) and aorta (c) of rats exposed to chronic hypoxia and normoxia. Each lane represents protein isolated from an individual animal. b, $\mathbf{d}$ Densitometric data obtained from immunoblots ( $\mathrm{n}=12-15$ animals). Twelve animals per treatment group were used to compile the data in $\mathbf{b}$ for $\alpha_{1}$ and $\alpha_{8}$ integrins, while 15 were used for all others. Data are normalized to the average of the normoxic controls. Asterisks show significant changes in integrin protein expression upon exposure to chronic hypoxia $\left({ }^{*} \mathrm{p}<0.05,{ }^{* *} \mathrm{p}<0.01\right.$ vs. control).

\section{Effect of Chronic Hypoxia on FAK Phosphorylation in} $P A s$ and PASMCs

To examine if the alterations in integrin expression were evidenced in integrin-dependent signaling pathways, phosphorylation of FAK in endothelium-denud- ed PAs of control and chronic hypoxic rats was determined by immunoblotting with antibodies specific for phosphorylated and total FAK. The signal ratio of phosphorylated over total FAK was significantly higher $(181.4 \pm 29.7 \%$ of normoxic control, $n=6, p<0.025)$ in 


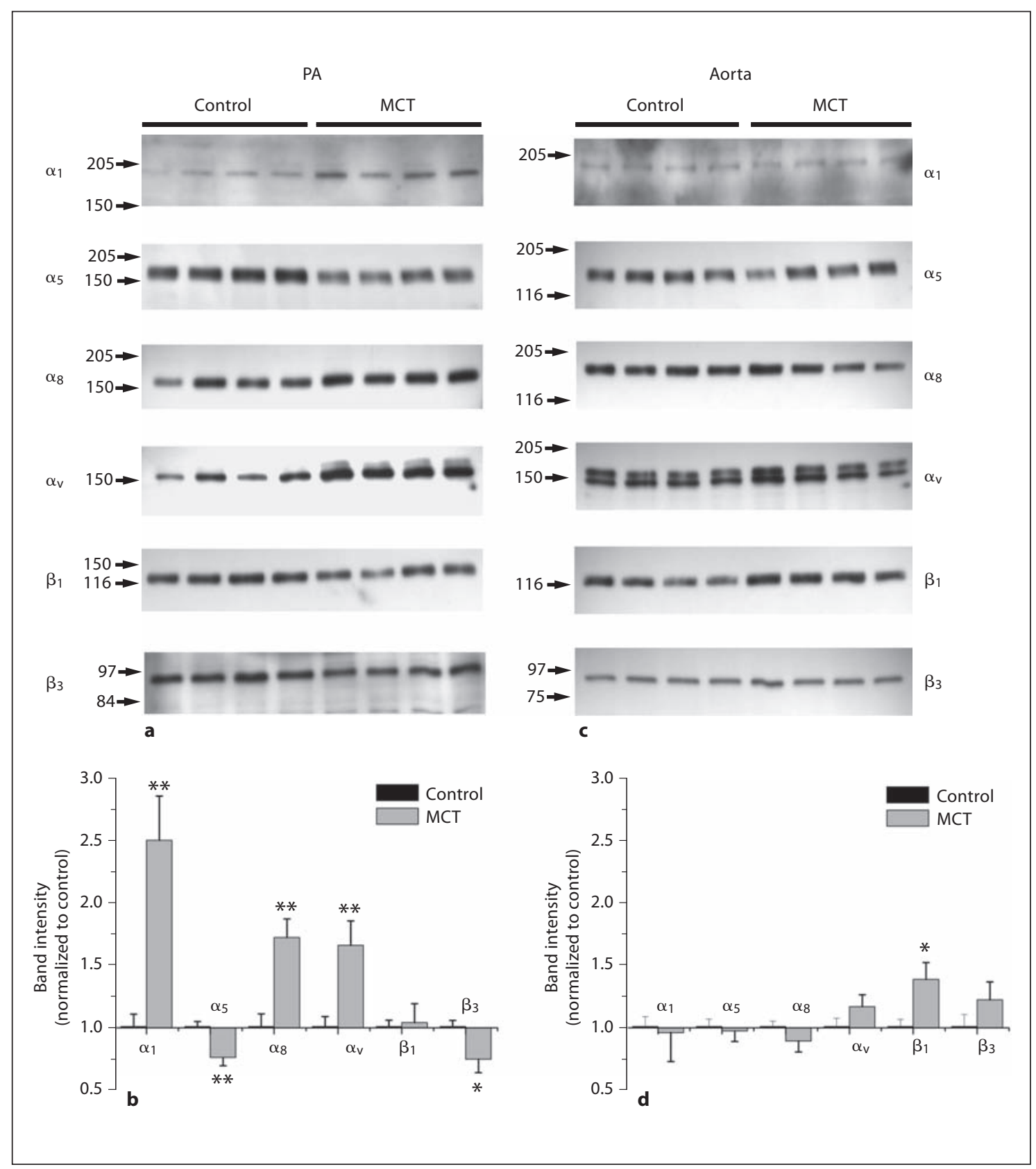

Fig. 2. Representative immunoblots of integrin proteins in endothelium-denuded PA (a) and aorta (c) of rats treated with MCT $(60 \mathrm{mg} / \mathrm{kg})$ for 24 days versus control. b, d Densitometric data obtained from immunoblots $(\mathrm{n}=11-12$ animals). Data are normalized to the average of the controls. Asterisks show significant changes in integrin protein expression upon treatment with $\mathrm{MCT}\left({ }^{*} \mathrm{p}<0.05,{ }^{* *} \mathrm{p}<0.01\right.$ vs. control).

the hypoxic PAs (fig. 5). FAK phosphorylation was also higher in PASMCs isolated from hypoxic rats (180.8 \pm $34.0 \%$ of normoxic control, $\mathrm{n}=4$ ), when transiently cultured ( $24 \mathrm{~h}$ ) on surfaces coated with type IV collagen, a ligand for the $\alpha_{1}$ integrin whose expression was elevated in hypoxic PASMCs (fig. 1a, b). In contrast, the differences of FAK phosphorylation between normoxic and hypoxic PASMCs disappeared when cells were cultured on fibronectin, a typical ligand for $\alpha_{5}$ integrin, whose expression was reduced by hypoxia (fig. 1a, b). 


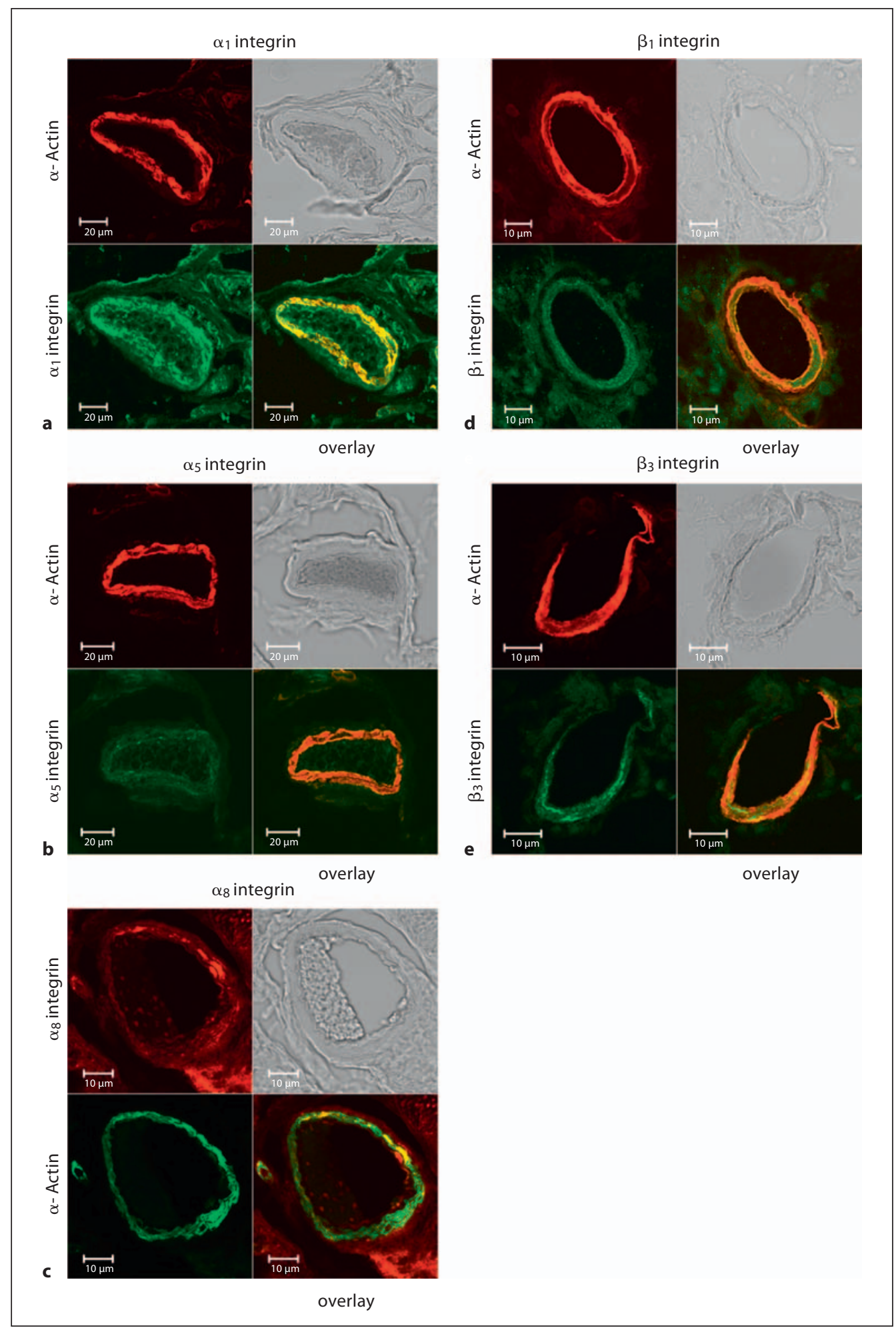

Fig. 3. Immunostaining of integrin and smooth muscle $\alpha$-actin in small PAs in lung sections of control rats. Confocal images show fluorescent signals from lung sections double-stained with a $\alpha_{1}$ (a), $\alpha_{5}$ (b), $\alpha_{8}$ (c), $\beta_{1}(\mathbf{d})$ and $\beta_{3}$ (e) integrin-specific antibody, and an $\alpha$-actin-specific antibody. Transmission images show the lung structures, while the yellow color indicates the regions in which there were overlaying of signals of integrin protein and $\alpha$-actin in PAs. The images were taken with a Plan Neofluar $\times 20$ objective (numerical aperture $=0.5$ ), pinhole size $=1$ airy, and zoom was between 2.7 and 3.6. Scale bars $=20 \mu \mathrm{m}(\mathbf{a}, \mathbf{b}) ; 10 \mu \mathrm{m}(\mathbf{c}-\mathbf{e})$. 


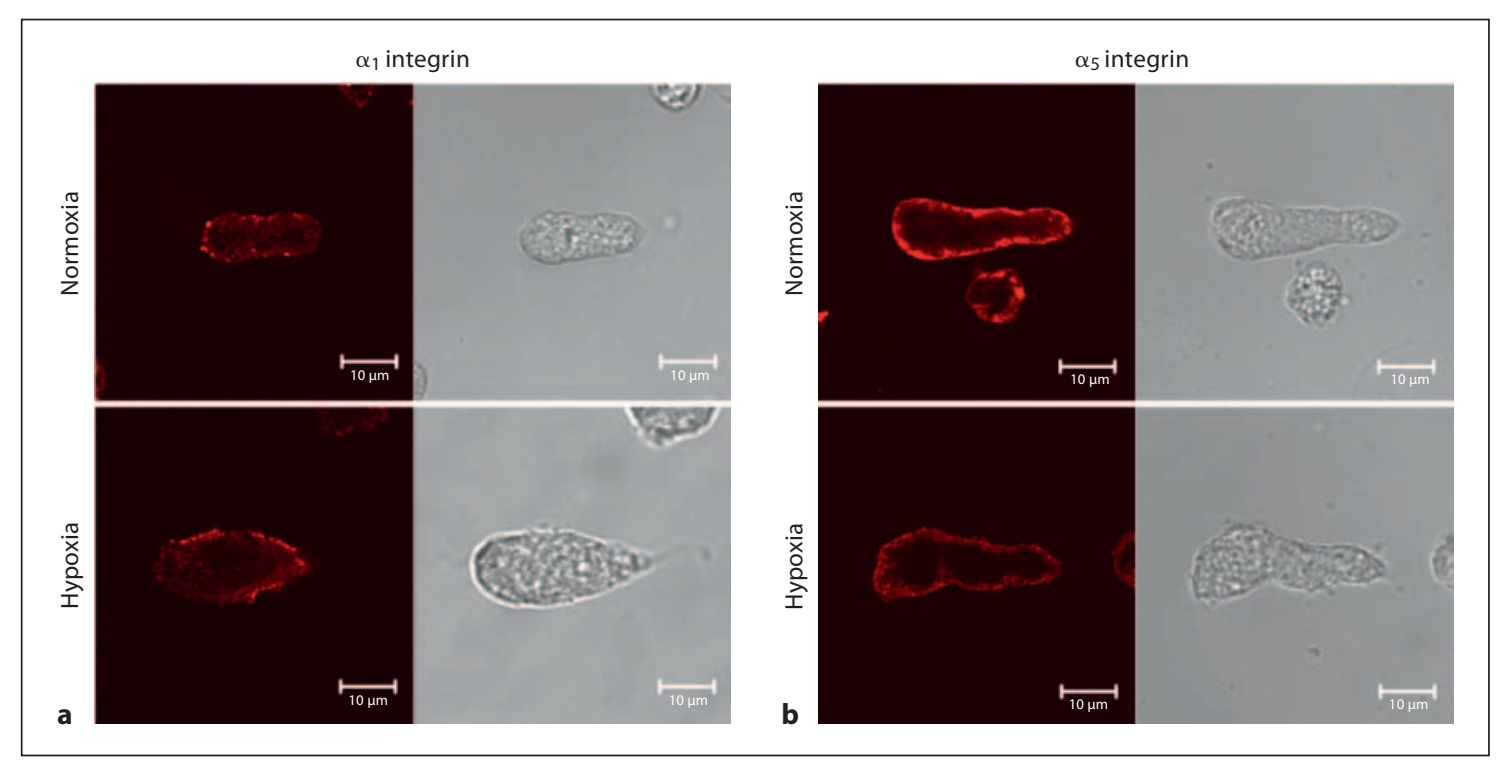

Fig. 4. Confocal images of immuno-fluorescent signals (red) of $\alpha_{1}$ (a) and $\alpha_{5}$ integrin (b) in PASMCs isolated from normoxic and chronic hypoxic rats. Transmitted light images (right panels) were included for reference. The images were taken with a Plan Neofluar $\times 40$ oil objective (numeric aperture $=1.3$ ), pinhole size $=1$ airy, and zoom $=4$. Laser power, sensitivity and gain were set at the same level for confocal imaging of the normoxic and hypoxic cells.

\section{RGD-Induced Calcium Signals}

To test if the changes in hypoxia-induced integrin expression are translated into altered physiological function, we monitored the $\left[\mathrm{Ca}^{2+}\right]_{\mathrm{i}}$ response to RGD peptides in PASMCs isolated from normoxic and chronic hypoxic rats. Integrin $\alpha_{1}$, whose expression was significantly upregulated upon exposure to chronic hypoxia, recognizes collagen types I and IV when dimerized with $\beta_{1}$ integrin. We therefore compared the intracellular $\mathrm{Ca}^{2+}$ response of PASMCs to GRGDTP, which preferentially interacts with receptors for collagen, including $\alpha_{1} \beta_{1}$ integrin [18].

Exogenous application of GRGDTP (1 mM) to PASMCs isolated from normoxic control rats elicited a maximum increase in $\left[\mathrm{Ca}^{2+}\right]_{\text {i }}$ of $73 \pm 16 \mathrm{nM}$ (fig. $6 \mathrm{a}$, b; at $10 \mathrm{~min}$, $\mathrm{n}=30$ dishes). When applied to PASMCs isolated from rats exposed to chronic hypoxia, GRGDTP caused $\left[\mathrm{Ca}^{2+}\right]_{\mathrm{i}}$ changes of a larger magnitude $\left(\Delta\left[\mathrm{Ca}^{2+}\right]_{\mathrm{i}}=114 \pm 24 \mathrm{nM}\right.$, at $3.5 \mathrm{~min}, \mathrm{n}=29$ dishes) than in normoxic PASMCs. Moreover, the time course of the $\left[\mathrm{Ca}^{2+}\right]_{\mathrm{i}}$ transient induced by GRGDTP was faster in the hypoxic cells, where the peak $\Delta\left[\mathrm{Ca}^{2+}\right]_{\mathrm{i}}$ was reached by $3.5 \mathrm{~min}$ after GRGDTP application, as opposed to $8 \mathrm{~min}$ in normoxic controls. At 3.5 min after GRGDTP application, the $\mathrm{Ca}^{2+}$ response observed in PASMCs isolated from chronic hypoxic rats was significantly larger than the normoxic controls (fig. 6b, $\mathrm{p}<0.001$ ).

To test if the decreased $\alpha_{5}$ integrin expression in the PAs of chronic hypoxic rats affected $\left[\mathrm{Ca}^{2+}\right]_{i}$ signaling, we utilized the hexapeptide GRGDNP, which predominantly targets the fibronectin receptor including $\alpha_{5} \beta_{1}$ integrin [19]. GRGDNP (0.5 mM) elicited a biphasic $\mathrm{Ca}^{2+}$ response with an initial peak followed by a sustained plateau phase (fig. 6c, d). The initial response in PASMCs isolated from normoxic and chronic hypoxic rats were similar, at 153 \pm 21 and $125 \pm 21 \mathrm{nM}$, respectively. However, the sustained phase of the GRGDNP-induced $\mathrm{Ca}^{2+}$ response was significantly reduced in PASMCs isolated from chronic hypoxic rats (34 $\pm 8 \mathrm{nM}, \mathrm{n}=27$ dishes) as compared to those isolated from normoxic controls $(79 \pm 12 \mathrm{nM}, \mathrm{n}=$ 26 dishes, $\mathrm{p}=0.003$ ).

\section{Discussion}

The present study extends our previous report on the characterization of integrin expression and $\mathrm{Ca}^{2+}$ response in rat PA smooth muscle [10]. Immunostaining shows that integrin proteins are expressed in $\alpha$-actin-positive smooth muscle layer in small PAs and localized in the surface of 


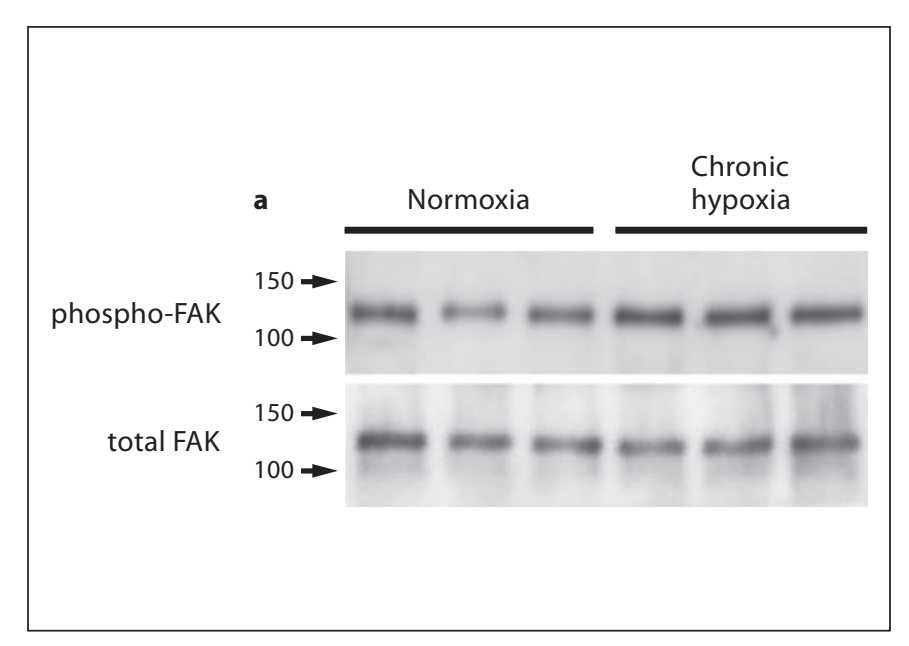

Fig. 5. a Representative immunoblots of phosphorylated FAK and total FAK in endothelium-denuded PAs from normoxic and hypoxic animals. Each lane represents protein isolated from an individual animal. b A bar graph summarizes the averaged signal ratio of phosphorylated FAK over total FAK in PAs ( $n=6$ animals in each group). c The signal ratio of phosphorylated FAK over total FAK in PASMCs isolated from normoxic and hypoxic rats that were transiently cultured in culture dish coated with collagen IV or fibronectin ( $\mathrm{n}=4$ experiments with cells from 4 different animals in each group). Asterisks show significant changes in increase in FAK phosphorylation upon exposure to chronic hypoxia (* $\mathrm{p}<0.05$ vs. normoxia).

PASMCs. The expression of integrin proteins is altered in endothelium-denuded PAs in chronic hypoxia and MCTinduced pulmonary hypertensive rats. Both models displayed significant increases in $\alpha_{1}, \alpha_{8}$ and $\alpha_{\mathrm{v}}$ integrins as well as a downregulation of $\alpha_{5}$ integrin. Integrin $\beta_{1}$ and $\beta_{3}$ protein levels were also significantly suppressed in chronic hypoxia and MCT-treated rats, respectively. Downstream integrin signaling was also affected in congruence with the altered integrin expression, such that the levels of FAK phosphorylation were augmented in PAs of chronically hypoxic rats, and the enhanced phosphorylation was further maintained in hypoxic PASMCs when cultured on the $\alpha_{1}$ integrin ligand collagen IV. Moreover, the upregulation of $\alpha_{1}$ integrin and the downregulation of $\alpha_{5}$ integrin in chronic hypoxic PAs were correlated with increased and decreased $\mathrm{Ca}^{2+}$ mobilization in PASMCs induced by RGD peptides that specifically target these in- b

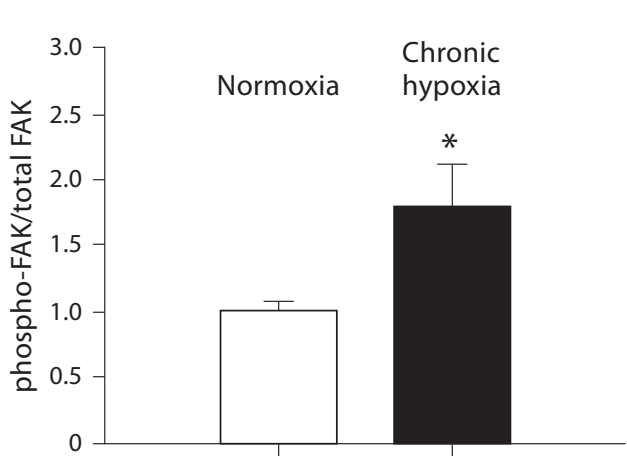

\section{c}

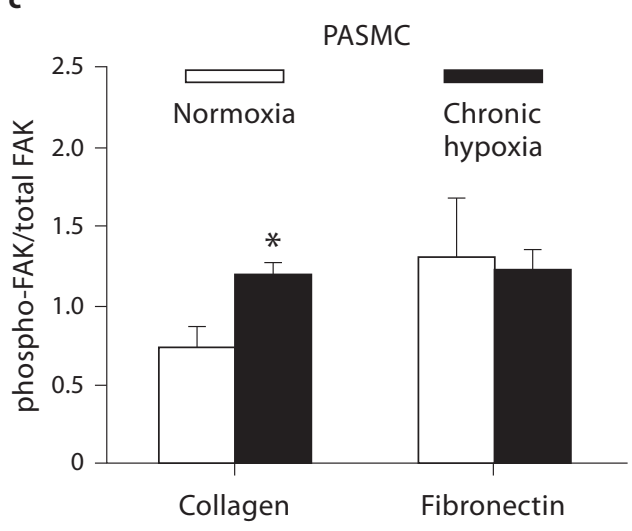

tegrins. The effects of both chronic hypoxia and MCT were specific to the pulmonary vasculature, as endothelium-denuded aorta from the same animals displayed virtually no change in integrin expression, except a small reduction of $\alpha_{8}$ integrin in the hypoxic animals and a minor increase in $\beta_{1}$ integrin in MCT treated rats. Our results therefore indicate that integrin expression and associated signaling pathways are altered in pulmonary hypertension and partake in pulmonary vascular remodeling that accompanies disease progression.

The differential regulation of integrins observed in this study underscores the complex interplay of ECM/integrin-dependent mechanisms, which depends on the temporal alterations in synthesis, deposition and reorganization of various ECM components, as well as the expression of specific integrins at different stages of disease progression. In the chronic hypoxia model, increased de- 


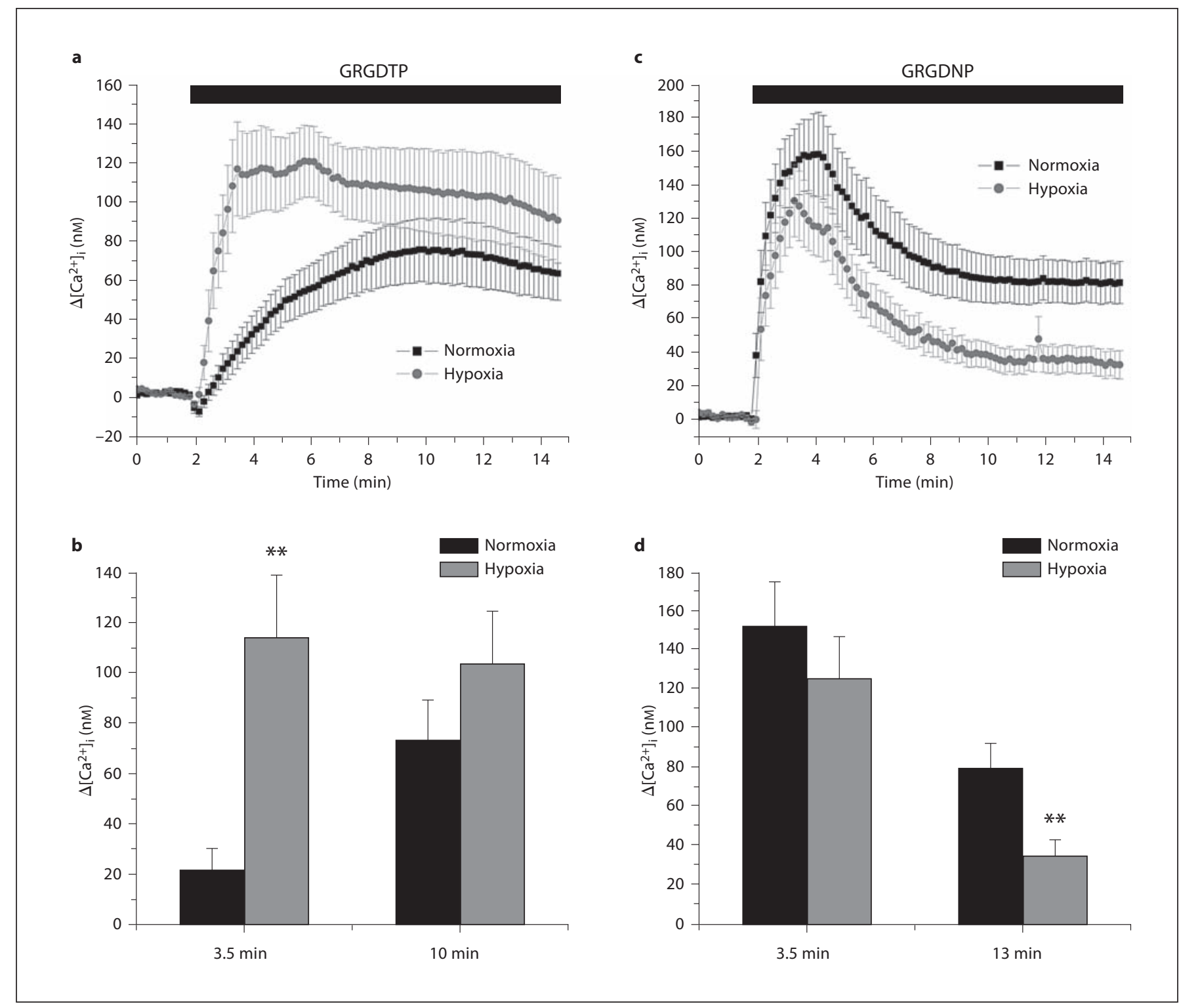

Fig. 6. $\left[\mathrm{Ca}^{2+}\right]_{\mathrm{i}}$ transients elicited by integrin-binding peptides in PASMCs from normoxic and chronic hypoxic rats. a Time course of GRGDTP-induced $\left[\mathrm{Ca}^{2+}\right]_{\mathrm{i}}$ response in normoxic (black squares) or chronic hypoxic (gray circles) PASMCs. $\mathrm{n}=29$ dishes of PASMCs, from 3 rats on 3 separate days. b Bar graph summarizing the peak and plateau phases of $\Delta\left[\mathrm{Ca}^{2+}\right]_{\mathrm{i}}$ at 3.5 and $10 \mathrm{~min}$ after application of GRGDTP. c Time course of GRGDNP-elicited $\left[\mathrm{Ca}^{2+}\right]_{i}$ response in normoxic (black squares) or chronic hypoxic (gray circles) PASMCs. $\mathrm{n}=30$ dishes of PASMCs, from 3 rats on 3 separate days. $\mathbf{d}$ Bar graph summarizing the peak and plateau phases of $\Delta\left[\mathrm{Ca}^{2+}\right]_{\mathrm{i}}$ at 3.5 and 13 min postapplication of GRGDNP. position of ECM components including collagen type I, III and IV, elastin, laminin as well as fibronectin has been reported [20-23]. Transcripts of type IV collagen increase within $6 \mathrm{~h}$ and decline after 10 days, whereas type I and III collagen as well as fibronectin mRNA increase after 3 days and then decline to the control level after 10 days of exposure to hypoxia [22]. Elevated levels of ECM proteins could be observed in 4 days of hypoxia and progress with time [23]. Similar increases in collagen, elastin, laminin, tenascin and fibronectin occur in the MCT model [2427]. Elevated mRNA levels of laminin and tenascin could be detected within one day, and the increases in immunolocalizable fibonectin, laminin, perlecan and type IV collagen protein around the vasculature could be ob- 
served 4 days after MCT treatment $[24,26]$. ECM components continue to increase as the disease develops. The present study at 4 weeks of chronic hypoxia and 24 days of MCT treatment, therefore, is a snapshot view of the alterations in integrin expression in established pulmonary hypertension.

Amongst the integrins surveyed in this study, $\alpha_{1}$ integrin was most prominently increased in both chronic hypoxia and MCT models of pulmonary hypertension. $\alpha_{1}$ integrin, when dimerized to $\beta_{1}$ integrin is a major receptor for collagen $[4,28]$, with a preference for type IV collagen, the basement membrane collagen [29]. In addition to type IV collagen adhesion, $\alpha_{1} \beta_{1}$ integrin mediates feedback regulation of type I collagen synthesis and collagen-dependent proliferation [29]. Its expression is associated with the differentiated phenotype of SMCs, where transition from a contractile to synthetic phenotype results in its downregulation at both transcript and protein levels $[28,30]$. Levels of the ligand, type IV collagen, are increased in PAs of animals with chronic hypoxia and MCT-induced pulmonary hypertension [3, 24], along with the expression and activity of MMP-2, which degrades collagen type IV $[1,6]$. Loss of intact type IV collagen accompanying basement membrane degradation is associated with SMC dedifferentiation and a correlative increase in SMC migration [31]. We hypothesize that the upregulation of $\alpha_{1}$ integrin in hypertensive PAs increases the sensitivity of PASMCs to intact type IV collagen, in order to maintain SMCs in a differentiated state counteracting the dedifferentiation process involved with the progression of pulmonary hypertension.

In addition to the $\alpha_{1}$ integrin, $\alpha_{\mathrm{v}}$ and $\alpha_{8}$ integrins are upregulated in PAs of chronic hypoxia and MCT-treated rats. $\alpha_{v}$-protein dimerizes with $\beta_{1}, \beta_{3}, \beta_{5}, \beta_{6}$, and $\beta_{8}$ integrins to recognize RGD-containing ligands, including vitronectin, fibronectin, fibrinogen, von Willebrand factor, thrombospondin, osteopontin and collagen [8]. Its increased protein levels in PAs isolated from chronic hypoxia and MCT-treated rats is consistent with previous studies in the systemic vasculature demonstrating, for example, its upregulation in small mesenteric arteries of hypertensive rats $[32,33]$ as well as in the neointima of various animal models of vascular injury [11, 32, 34]. $\alpha_{v} \beta_{3}$ integrin is furthermore involved in PASMC hyperplasia in the MCT model of pulmonary hypertension [ 1 , $12,13]$. Many studies including those in the pulmonary vasculature show reduced vascular response to injury via decreased SMC proliferation and migration, MMP production and increased SMC apoptosis upon $\alpha_{v} \beta_{3}$ inhibition [34-37]. The increase in $\alpha_{v}$ integrin observed in this study may contribute to PASMC proliferation and migration in pulmonary hypertension as a part of the vascular remodeling process.

$\alpha_{8}$ integrin is highly expressed in vascular smooth muscle and dimerizes with $\beta_{1}$ integrin to bind ligands such as tenascin- $C$, vitronectin and fibronectin $[8,38$, 39]. Expression of $\alpha_{8} \beta_{1}$ integrin has been proposed as required for maintaining the contractile, differentiated phenotype of vascular SMCs. Indeed, $\alpha_{8}$ integrin expression is decreased during neointimal formation. $\alpha_{8}$ integrin gene silencing increases vascular SMC migration and expression of SMC de-differentiation markers. $\alpha_{8}$ integrin overexpression attenuates SMC migratory activity and restores contractile phenotypes [11, 38, 39]. On the other hand, integrin $\alpha_{5} \beta_{1}$, the prototypical receptor for fibronectin, acts as a signal for cell proliferation [40,41]. It is involved in the polymerization of fibronectin, which promotes SMC replication, migration and survival, and the overall maintenance of a synthetic phenotype [41]. $\alpha_{5}$ integrin was decreased in both models of pulmonary hypertension. Thus, the upregulation of $\alpha_{8}$ integrin and downregulation of $\alpha_{5}$ integrin PAs obtained from both models of pulmonary hypertension may provide feedback signals to maintain the contractile phenotype of PASMCs and offset pulmonary vascular remodeling.

Compared to the large repertoire of $\alpha$-subunits, the number of $\beta$ integrins is limited. Only $8 \beta$ integrins are available to heterodimerize with $18 \alpha$-subunits. Of the 24 $\alpha \beta$ heterodimers identified to date, 12 contain the $\beta_{1}$, while the major partner for $\beta_{3}$ integrin is $\alpha_{\mathrm{v}}[8]$. $\beta_{1}$ and $\beta_{3}$ integrins were decreased in PAs of chronic hypoxia and MCT models of pulmonary hypertension, respectively. Inhibition of $\beta_{1}$ integrin has been shown to reduce vascular SMC migration and adhesion [42, 43], and knockout as well as blockade of $\beta_{3}$ integrin decreased neointimal thickening and SMC migration in injured arteries [37, 44]. Since $\beta$ integrins heteromerize with various $\alpha$-subtypes, the modest decrease in $\beta_{1}$ and $\beta_{3}$ levels may limit the availability of functionally active heterodimeric integrins, although its significance within the context of pulmonary hypertension is presently unclear.

The changes in integrin protein expression detected by immunoblot in PA of pulmonary hypertensive rat models are likely translated into alterations of integrindependent signaling. This is evidenced by further examining the functional consequences of differential $\alpha_{1}$ and $\alpha_{5}$ integrin expression in the chronic hypoxia model. $\alpha_{1}$ and $\alpha_{5}$ integrins were chosen due to the availability of RGD peptides and ECM proteins that target these integrins relatively specifically. The predominant $\alpha_{1}$ and $\alpha_{5}$ 
integrin immunoreactivity on the surface of PASMCs of chronically hypoxic rats suggest that the integrin proteins are incorporated into the sarcolemma, precluding the possibility that cytosolic accumulation of nonfunctional integrin proteins may contribute to the immunoblot data. A higher integrin-dependent activity is supported by the elevated level of FAK phosphorylation, a major downstream signaling pathway, in PASM of hypoxic rats. The enhanced phosphorylation could be related in part to the upregulated $\alpha_{1}$ integrin because it was maintained in PASMCs isolated from hypoxic rats that were cultured on the $\alpha_{1} \beta_{1}$ ligand type IV collagen, but not on the $\alpha_{5} \beta_{1}$ ligand fibronectin. Upregulation of $\alpha_{1}$ integrin in the chronic hypoxic PASMCs was furthermore reflected in the increased $\mathrm{Ca}^{2+}$ mobilization elicited by the $\alpha_{1}$ integrin-binding peptide, GRGDTP, in a manner similar to the collagen IV-induced $\mathrm{Ca}^{2+}$ response observed in other cell types $[45,46]$. Likewise, the decreased $\alpha_{5}$ integrin expression correlated with the reduced sustained $\mathrm{Ca}^{2+}$ response of chronic hypoxic PASMCs to the $\alpha_{5}$ integrin-binding hexapeptide, GRGDNP. It has to be mentioned, however, that the $\mathrm{Ca}^{2+}$ response induced by soluble RGD peptide ligands may only partially reflect the signaling induced by the immobile ligands within the native tissue.

The unique kinetic profiles of the intracellular $\mathrm{Ca}^{2+}$ transients elicited by the hexapeptides, GRGDTP and GRGDNP, suggest that integrins mobilize intracellular $\mathrm{Ca}^{2+}$ through subtype-specific pathways. Indeed, although both $\alpha_{v} \beta_{3}$ and $\alpha_{5} \beta_{1}$ integrins are necessary for myogenic constriction in cremester arterioles [47], $\alpha_{5} \beta_{1}$ integrin activation causes vasoconstriction through $\mathrm{L}$ type $\mathrm{Ca}^{2+}$ channel potentiation, while $\alpha_{\mathrm{v}} \beta_{3}$ ligands induce vasodilation, $\mathrm{K}^{+}$current activation and L-type $\mathrm{Ca}^{2+}$ channel inhibition [9]. We have also shown that the com- mon integrin ligand GRGDSP mediates $\mathrm{Ca}^{2+}$ release from ryanodine-gated $\mathrm{Ca}^{2+}$ stores and lysosome-related acidic organelles in rat PASMCs [10]. The diverse modes of $\mathrm{Ca}^{2+}$ mobilization transduced by the various integrins are likely linked to the ultimate downstream effect and function of the specific integrins. It will be important in the future to address the $\mathrm{Ca}^{2+}$ signaling pathways linked to the specific integrins that are altered in pulmonary hypertension.

In summary, we quantified the integrin levels in PAs of chronic hypoxia and MCT-induced pulmonary hypertensive rats. The similarity in the regulation of $\alpha$-integrin expression in the two models suggest that they are related generally to pulmonary hypertension, and not to the direct effects of hypoxia or MCT on the pulmonary vasculature. The differential regulation of integrins in the PAs of pulmonary hypertensive animals exemplifies the complex nature of ECM/integrin-mediated signaling, and underscores the multifactorial nature of the mechanisms involved in pulmonary hypertension. Although the exact mechanisms leading to the development of pulmonary hypertension are a topic of active debate, the results of this study highlighting the involvement of a new player, namely integrins, in pulmonary hypertension along with its ECM ligands that play a major role in disease pathogenesis.

\section{Acknowledgments}

We thank Dr. Lynn Schapp (University of Washington) for generously providing the antiserum to $\alpha_{8}$ integrin, Lionel McIntosh and Holly Rohde for technical assistance, and Dr. Xiao-Ru Yang for sage advice. This work was supported in part by National Heart, Lung, and Blood Institute grants HL-071835 and HL075134 to J.S.K.S. and a Pulmonary Hypertension Association Postdoctoral Fellowship Award to A.U.

\section{References}

$\rightarrow 1$ Humbert M, Morrell NW, Archer SL, Stenmark KR, MacLean MR, Lang IM, Christman BW, Weir EK, Eickelberg O, Voelkel NF, Rabinovitch M: Cellular and molecular pathobiology of pulmonary arterial hypertension. J Am Coll Cardiol 2004;43:13S$24 \mathrm{~S}$.

-2 Botney MD, Kaiser LR, Cooper JD, Mecham RP, Parghi D, Roby J, Parks WC: Extracellular matrix protein gene expression in atherosclerotic hypertensive pulmonary arteries. Am J Pathol 1992;140:357-364.

3 Crouch EC, Parks WC, Rosenbaum JL, Chang D, Whitehouse L, Wu LJ, Stenmark
KR, Orton EC, Mecham RP: Regulation of collagen production by medial smooth muscle cells in hypoxic pulmonary hypertension. Am Rev Respir Dis 1989;140:10451051.

4 Durmowicz AG, Stenmark KR: Mechanisms of structural remodeling in chronic pulmonary hypertension. Pediatr Rev 1999;20:e91e102.

$\checkmark 5$ Zaidi SH, You XM, Ciura S, Husain M, Rabinovitch M: Overexpression of the serine elastase inhibitor elafin protects transgenic mice from hypoxic pulmonary hypertension. Circulation 2002;105:516-521.
-6 Hassoun PM: Deciphering the 'matrix' in pulmonary vascular remodelling. Eur Respir J 2005;25:778-779.

$\checkmark 7$ Cowan KN, Heilbut A, Humpl T, Lam C, Ito S, Rabinovitch M: Complete reversal of fatal pulmonary hypertension in rats by a serine elastase inhibitor. Nat Med 2000;6:698-702.

8 Humphries JD, Byron A, Humphries MJ: Integrin ligands at a glance. J Cell Sci 2006;119: 3901-3903.

-9 Martinez-Lemus LA, Wu X, Wilson E, Hill MA, Davis GE, Davis MJ, Meininger GA: Integrins as unique receptors for vascular control. J Vasc Res 2003;40:211-233. 
$\checkmark 10$ Umesh A, Thompson MA, Chini EN, Yip KP, Sham JS: Integrin ligands mobilize $\mathrm{Ca}^{2+}$ from ryanodine receptor-gated stores and lysosome-related acidic organelles in pulmonary arterial smooth muscle cells. J Biol Chem 2006;281:34312-34323.

11 Heerkens EH, Izzard AS, Heagerty AM: Integrins, vascular remodeling, and hypertension. Hypertension 2007;49:1-4.

12 Jones PL, Jones FS, Zhou B, Rabinovitch M: Induction of vascular smooth muscle cell tenascin- $\mathrm{C}$ gene expression by denatured type I collagen is dependent upon a beta 3 integrin-mediated mitogen-activated protein kinase pathway and a 122-base pair promoter element. J Cell Sci 1999;112(Pt 4):435-445.

13 Jones PL, Crack J, Rabinovitch M: Regulation of tenascin- $\mathrm{C}$, a vascular smooth muscle cell survival factor that interacts with the alpha $\mathrm{v}$ beta 3 integrin to promote epidermal growth factor receptor phosphorylation and growth. J Cell Biol 1997;139:279-293.

- 14 Bull TM, Coldren CD, Geraci MW, Voelkel NF: Gene expression profiling in pulmonary hypertension. Proc Am Thorac Soc 2007; 4 : 117-120.

15 Shimoda LA, Sham JS, Shimoda TH, Sylvester JT: L-type $\mathrm{Ca}^{2+}$ channels, resting $\left[\mathrm{Ca}^{2+}\right]_{\mathrm{i}}$, and ET-1-induced responses in chronically hypoxic pulmonary myocytes. Am J Physiol Lung Cell Mol Physiol 2000;279:L884-894.

16 Jones R, Jacobson M, Steudel W: alphasmooth-muscle actin and microvascular precursor smooth-muscle cells in pulmonary hypertension. Am J Respir Cell Mol Biol 1999;20:582-594.

17 Zhong H, Simons JW: Direct comparison of GAPDH, $\beta$-actin, cyclophilin, and 28S rRNA as internal standards for quantifying RNA levels under hypoxia. Biochem Biophys Res Commun 1999;259:523-526.

18 Dedhar S, Ruoslahti E, Pierschbacher MD: A cell surface receptor complex for collagen type I recognizes the Arg-Gly-Asp sequence. J Cell Biol 1987; 104:585-593.

19 Pierschbacher MD, Ruoslahti E: Influence of stereochemistry of the sequence Arg-GlyAsp-Xaa on binding specificity in cell adhesion. J Biol Chem 1987;262:17294-17298.

20 Poiani GJ, Tozzi CA, Yohn SE, Pierce RA, Belsky SA, Berg RA, Yu SY, Deak SB, Riley DJ: Collagen and elastin metabolism in hypertensive pulmonary arteries of rats. Circ Res 1990;66:968-978.

-21 Estrada KD, Chesler NC: Collagen-related gene and protein expression changes in the lung in response to chronic hypoxia. Biomech Model Mechanobiol 2009;8:263-272.

-22 Berg JT, Breen EC, Fu Z, Mathieu-Costello $\mathrm{O}$, West JB: Alveolar hypoxia increases gene expression of extracellular matrix proteins and platelet-derived growth factor-B in lung parenchyma. Am J Respir Crit Care Med 1998;158:1920-1928.

23 Vyas-Somani AC, Aziz SM, Arcot SA, Gillespie MN, Olson JW, Lipke DW: Temporal alterations in basement membrane compo- nents in the pulmonary vasculature of the chronically hypoxic rat: impact of hypoxia and recovery. Am J Med Sci 1996;312:54-67.

24 Lipke DW, Arcot SS, Gillespie MN, Olson JW: Temporal alterations in specific basement membrane components in lungs from monocrotaline-treated rats. Am J Respir Cell Mol Biol 1993;9:418-428.

-25 Tanaka Y, Bernstein ML, Mecham RP, Patterson GA, Cooper JD, Botney MD: Site-specific responses to monocrotaline-induced vascular injury: evidence for two distinct mechanisms of remodeling. Am J Respir Cell Mol Biol 1996;15:390-397.

26 Lipke DL, Aziz SM, Fagerland JA, Majesky M, Arcot SS: Tenascin synthesis, deposition, and isoforms in monocrotaline-induced pulmonary hypertensive rat lungs. Am J Physiol 1996;271:L208-L215.

-27 Todorovich-Hunter L, Johnson DJ, Ranger P, Keeley FW, Rabinovitch M: Altered elastin and collagen synthesis associated with progressive pulmonary hypertension induced by monocrotaline. A biochemical and ultrastructural study. Lab Invest 1988;58:184195.

28 Belkin VM, Belkin AM, Koteliansky VE: Human smooth muscle VLA-1 integrin: purification, substrate specificity, localization in aorta, and expression during development. J Cell Biol 1990;111:2159-2170.

29 Heino J: The collagen receptor integrins have distinct ligand recognition and signaling functions. Matrix Biol 2000;19:319-323.

- 30 Obata H, Hayashi K, Nishida W, Momiyama T, Uchida A, Ochi T, Sobue K: Smooth muscle cell phenotype-dependent transcriptional regulation of the $\alpha 1$ integrin gene. J Biol Chem 1997;272:26643-26651.

- 31 Aguilera CM, George SJ, Johnson JL, Newby AC: Relationship between type IV collagen degradation, metalloproteinase activity and smooth muscle cell migration and proliferation in cultured human saphenous vein. Cardiovasc Res 2003;58:679-688.

32 Heerkens EH, Shaw L, Ryding A, Brooker G, Mullins JJ, Austin C, Ohanian V, Heagerty AM: $\alpha_{\mathrm{v}}$ integrins are necessary for eutrophic inward remodeling of small arteries in hypertension. Hypertension 2006;47:281287.

33 Intengan HD, Thibault G, Li JS, Schiffrin EL: Resistance artery mechanics, structure, and extracellular components in spontaneously hypertensive rats: effects of angiotensin receptor antagonism and converting enzyme inhibition. Circulation 1999;100: 2267-2275.

- 34 van der Zee R, Murohara T, Passeri J, Kearney M, Cheresh DA, Isner JM: Reduced intimal thickening following $\alpha_{v} \beta_{3}$ blockade is associated with smooth muscle cell apoptosis. Cell Adhes Commun 1998;6:371-379.

-35 Merklinger SL, Jones PL, Martinez EC, Rabinovitch M: Epidermal growth factor receptor blockade mediates smooth muscle cell apoptosis and improves survival in rats with pulmonary hypertension. Circulation 2005; 112:423-431.

- 36 Bendeck MP, Irvin C, Reidy M, Smith L, Mulholland D, Horton M, Giachelli CM: Smooth muscle cell matrix metalloproteinase production is stimulated via $\alpha_{\mathrm{v}} \beta_{3}$ integrin. Arterioscler Thromb Vasc Biol 2000; 20:1467-1472.

37 Slepian MJ, Massia SP, Dehdashti B, Fritz A, Whitesell L: $\beta_{3}$-integrins rather than $\beta_{1}$-integrins dominate integrin-matrix interactions involved in postinjury smooth muscle cell migration. Circulation 1998;97:18181827.

38 Zargham R, Touyz RM, Thibault G: $\alpha_{8}$ Integrin overexpression in de-differentiated vascular smooth muscle cells attenuates migratory activity and restores the characteristics of the differentiated phenotype. Atherosclerosis 2007; 195:303-312.

39 Zargham R, Thibault G: $\alpha_{8} \beta_{1}$ Integrin expression in the rat carotid artery: involvement in smooth muscle cell migration and neointima formation. Cardiovasc Res 2005; 65:813-822.

-40 Davenpeck KL, Marcinkiewicz C, Wang D, Niculescu R, Shi Y, Martin JL, Zalewski A: Regional differences in integrin expression: role of $\alpha_{5} \beta_{1}$ in regulating smooth muscle cell functions. Circ Res 2001;88:352-358.

41 Pickering JG, Chow LH, Li S, Rogers KA, Rocnik EF, Zhong R, Chan BM: $\alpha_{5} \beta_{1}$ integrin expression and luminal edge fibronectin matrix assembly by smooth muscle cells after arterial injury. Am J Pathol 2000;156: 453-465.

42 Itoh H, Nelson PR, Mureebe L, Horowitz A, Kent KC: The role of integrins in saphenous vein vascular smooth muscle cell migration. J Vasc Surg 1997;25:1061-1069.

43 Lee RT, Berditchevski F, Cheng GC, Hemler $\mathrm{ME}$ : Integrin-mediated collagen matrix reorganization by cultured human vascular smooth muscle cells. Circ Res 1995;76:209_ 214.

44 Choi ET, Khan MF, Leidenfrost JE, Collins ET, Boc KP, Villa BR, Novack DV, Parks WC, Abendschein DR: $\beta_{3}$-integrin mediates smooth muscle cell accumulation in neointima after carotid ligation in mice. Circulation 2004;109:1564-1569.

45 Somogyi L, Lasic Z, Vukicevic S, Banfic H: Collagen type IV stimulates an increase in intracellular $\mathrm{Ca}^{2+}$ in pancreatic acinar cells via activation of phospholipase C. Biochem J 1994;299:603-611.

-46 Savarese DM, Russell JT, Fatatis A, Liotta LA: Type IV collagen stimulates an increase in intracellular calcium. Potential role in tumor cell motility. J Biol Chem 1992;267: 21928-21935.

- 47 Martinez-Lemus LA, Crow T, Davis MJ, Meininger GA: $\alpha_{v} \beta_{3^{-}}$and $\alpha_{5} \beta_{1^{-} \text {-integrin }}$ blockade inhibits myogenic constriction of skeletal muscle resistance arterioles. Am J Physiol Heart Circ Physiol 2005;289:H322H329. 